$\xi=-1$

\title{
Capital Structure and Performance due to Gender Diversity of CEOs in Indonesian Small \& Medium-sized Business
}

\author{
Farida Titik Kristanti1 and Sri Rahayu2 \\ 1Department of Accounting \\ Faculty of Economics \& Business, Telkom University, West Java, Indonesia \\ farida_titik@yahoo.com faridatk@telkomuniversity.ac.id \\ 2Department of Accounting \\ Faculty of Economics \& Business, Telkom University, West Java, Indonesia \\ *Corresponding author E-mail: srirahayunchi@yahoo.co.id
}

\begin{abstract}
Previous researches and results show that women-owned small firms have less debt than man-owned firms, and they have different performance. The objective of this study is to know whether the difference of capital structure is a factor correlated with gender differences resulting in different financial performance. This study utilizes sample data of all small and medium-sized businesses listed in Indonesia Stock Exchange to determine the differences of capital structure and performance between companies with male and female CEOs. The statistical test result using independent t-test shows that there is no difference in both of them. Regression result shows variables influencing capital structure of small and medium-sized businesses in Indonesia are age of company, company size and company liquidity. Meanwhile, for company performance, the statistical test result shows that it is only variables of age of company and leverage that have significant effect. Therefore, small and medium-sized businesses should maintain their capital structure at low rates to have a good financial performance. Companies that are able to survive in a long term will also increase the company performance.
\end{abstract}

Keywords: Capital Structure, CEO Gender, Small and Medium-Sized Business

\section{Introduction}

Topic about capital structure has been discussed since [7] who proposed that debt is irrelevance. Other theory is proposed by [15], that the cost of both tax and bankruptcy makes relevant. Information asymmetry from [21] and [9] stated between managers and investors is also related with capital structure. Likewise, based on agency theory by [20] states the conflict between managers, owners, and bondholders relates with the capital structure of the company.

The women's business-owned ability to access financing has been the subject of research and debate over the last 15 years, but the gender gap in access to debt capital has been extensively studied [4]. According to those relatively few studies have been published in connection with the access of women owners to, and use, other external financing forms including supplier financing and external equity.

The number of small business in Indonesia in 2015 grew to 42.5 million from 36.5 million in 2013 , but the loan proportion declined as much as $26.2 \%$ (Roy Morgan Research, July 2015, downloaded on Des 28, 2015). The main problem often occurs is the limited access to capital source for small companies compared to larger companies. Difficulties over access to public debt and stock market cause small companies tend to rely on banks as the source of funding for their financial needs [19].

A number of studies about the comparison of capital structure between small companies and larger companies have been conducted [20] \& [15]. The result shows that small companies use more debts, particularly short-term debts than larger companies. On the other hand, speaking about gender differences, a study by [19] found that women-owned firms had lower sales and profit and employed fewer workers than men-owned firms. This study also proves that the lower performance could be explained by the low capital used to start business and their previous experiences. Although this study is inconsistent, it appears that the study shows that there is a relationship between financial capital and company performance [3]. Companies with more capital source will have more ability to survive, have higher growth level, and also show high earnings and profit.

Quoted from a report on bisniskeuangan.kompas.com, on a global scale, the number of female CEOs decreased to less than 3 percent in 2015, the lowest percentage since 2011. There were only 10 female CEOs out of 359 CEOs chairing boards in 2015. The number of female CEOs is only $4.8 \%$ from Fortune 500 companies. However, the low number of women in CEO boards does not only happen in the United States. In Scandinavia, there are only 3\% of female CEOs from 145 largest companies of Scandinavia. There are many studies have been conducted on gender roles in financial risk areas. It is indicated that women are more risk averse than men.

This study will analyze capital structure on small and mediumsized businesses listed in Indonesia Stock Exchange differentiated between companies with male and female CEOs. It is expected that they have different decision making in the capital structure. Decision in capital structure will impact the company performance. Therefore, this study will also analyze the performance of companies in small and medium-sized listed. This study also wants to 
see the difference of capital structure and performance between companies led by men and women.

This study is expected to provide contribution as follows: (1) Empirical study on the different between capital structure and performance between small and medium-sized businesses led by women or men. (2) Science development particularly in financial management studying capital structure and performance for small and medium-sized businesses led by women or men.

\section{Literature Review}

The companies will choose a mix between debt and their own capital that will maximize the company value and minimize the average capital cost [7]. Since the interest cost is tax deductible, debt is cheaper than the capital itself as the capital source. Small or young companies probably tend to rely on internal sources that comes from earnings or informal sources such as family or friends as their capital. As the company grows, more capital will be required that the company needs external financial source. Pecking order Theory by [21] states that companies will use internal funding sources in the form of retained profit before using external funding sources.

Asymmetric information between borrowers and lenders will also generate problems for small business [18]. The absence of suffient information makes banks refuse the load proposed. As a result, it is easier for small business to experience financial distress and failure. According to [24], the failure rate is more than 50\%.

Several studies have consistent results that women-owned firms are smaller than men-owned firms [22]. There is a myth that women do not want high corporate growth [5]. On the other hand study by [6] in Sweden found that gender is not a significant determinant for performance.

There are many studies conducted about the relationship between capital and performance. In norway, [11] found that womenowned firms significantly used lower capital than men-owned firms. The study also found that women-owned firms had lower level of sales and growth than men-owned firms. Study by [13] in Portugal found that leverage is positively correlated with firm size, asset composition, and firm growth and negatively correlated with firm's profitability. In Chinese, [8] collected data from more than 1000 Chinese listed companies up to the year 2000 and found that leverage increases with firm size, non-debt tax shields and fixed assets, and decreases with profitability. The studied by [23] found a positive relationship between firm growth and debt. The studied of [2] found that leverage is negatively correlated with collateralized assets and firm's profitability. Otherwise, [1] took a sample of 166 Canadian firms listed found that financial leverage is positively affected by firm size and negatively affected by collateralized assets, effective tax rate, firm performance, and firm growth. While the study of ROA has been done by [8] showed that corporate performance is adversely affected by indebtedness and positively related with company size. In Malaysia, [17] and [18] in Jordania, they also investigated the impact of capital structure on firm performance.

\section{Research Method}

Small and medium-sized businesses in this study are comply with criteria stated in Law Number 20, Chapter IV Article 6 Year 2008 stating that Small Business is small enterprise with annual sales worth more than IDR 300,000,000 (three hundred million rupiah) up to the most IDR 2,500,000,000 (two billion five hundred million rupiah). On the other hand, the criteria for Medium Business are as follows: has annual sale more than IDR 2,500,000,000 (two billion five hundred million rupiah) up to a maximum of IDR 50,000,000,000 (five billion rupiah).

Population in this study is all companies listed in Indonesia Stock Exchange. Samples were choses using purposive random sampling, and the criteria are that the research variable data during 20122014 should be available and comply with the criteria of small and medium-sized businesses. As a result, 26 companies complied with the criteria.

Differences between companies led by women and men are assessed with t-test. Meanwhile, regression analysis was used to see the influence of independent variables towards capital structure and performance on small and medium-scaled business led by men and women listed in Indonesia Stock Exchange.

Regression model used are:

$$
\begin{aligned}
& \mathrm{LEV}=\mathrm{a}+\mathrm{b}_{1} \mathrm{AGE}+\mathrm{b}_{2} \text { SIZE }+\mathrm{b}_{3} \text { GROWTH }+\mathrm{b}_{4} \mathrm{CR}+\mathrm{e} \\
& \text { ROA }=\mathrm{a}+\mathrm{b}_{1} \mathrm{AGE}+\mathrm{b}_{2} \text { SIZE }+\mathrm{b}_{3} \text { GROWTH }+\mathrm{b}_{4} \mathrm{CR}+\mathrm{b}_{5} \mathrm{LEV} \\
& +\mathrm{e}
\end{aligned}
$$

LEV is measured by total debt to total asset.

AGE is the age of the company from since established until now. SIZE is measured by $\log$ of Total asset. GROWTH is growth of sales. CR is current asset/total asset. ROA is measured by EAT/Equity.

\section{Result and discussion}

To see the differences between capital structure and performance between small and medium companies led by men and women, independent t-test is utilized. Statistical tests (Table 1) showed that the result of the probability of F Lavene test is simply the Leverage and ROA need to use Equal Variance not Assumed because it has the probability of 0,19 and 0,23 which are bigger than 0.05 . These results indicate that there is a different of leverage between small and medium companies whose CEOs are men and women. However, this study found no evidence that any performance difference (measured by ROA) leverage between small and medium companies whose CEOs are men and women. These indicates than women who tend to avoid risk will be more careful in making decisions. Leverage reflects how much total debt the company has, the greater the leverage the greater the risk (to not pay) that the company has. This is not in accordance with the statement that high risk high return. Small and medium companies whose CEOs are women in Indonesia have low debt but have relatively high performance (although different test shows there is no ROA difference between them). This is because women tend to be more careful in making business decisions so that on average the performance of companies they lead have better financial performance. The result of statistic descriptives (Table 2) shows that small and medium companies led by women have smaller average of leverage (0.1317 than 0.99150), but Small and medium companies led by women have better performance than small and medium companies led by men (-1.6717 than -3.8049$)$.

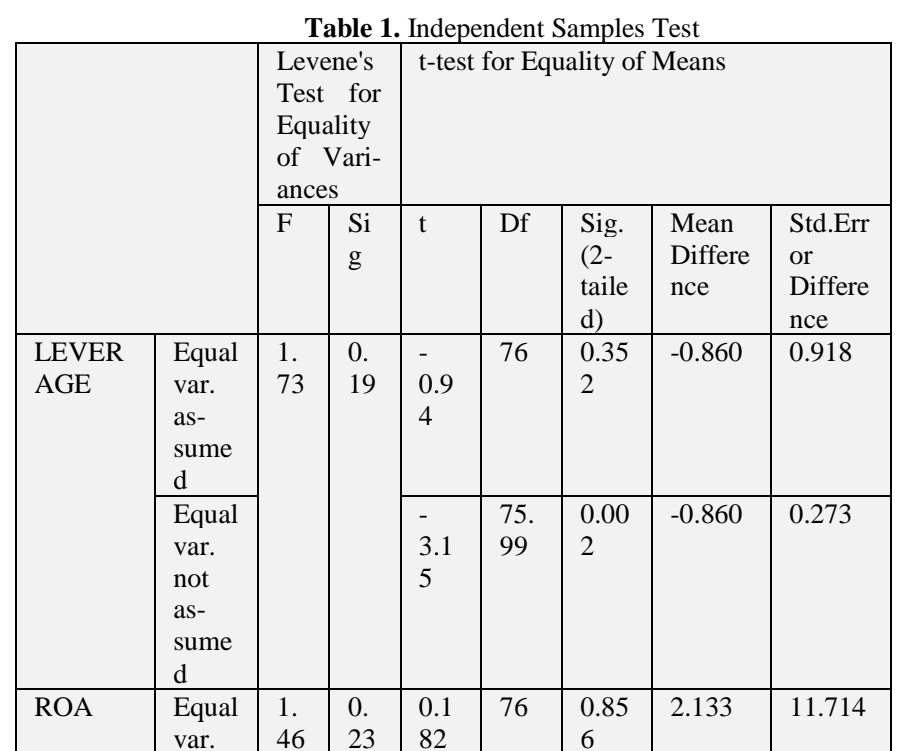




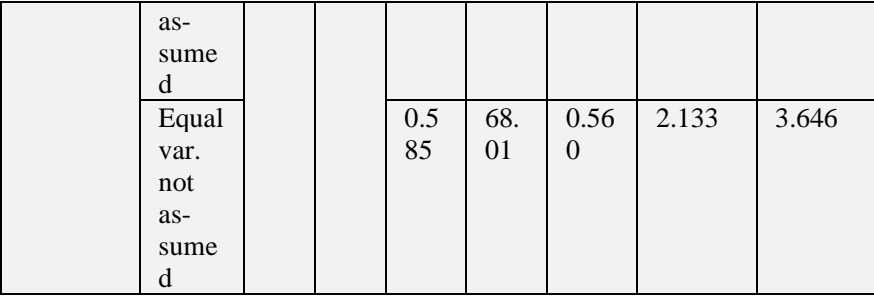

Source: Estimation results

The results of these studies are consistent with [8 in Sweden that found that gender is not a significant determinant for performance and [14] in his study in Norway found that women-owned firms significantly used lower capital than men-owned firms. This study also supports the myth that women do not want high corporate growth [7] and that women enterpreneurs play it safe in financing [16].

Table 2. Statistic Descriptives

\begin{tabular}{|l|l|l|l|l|l|}
\hline & Gender & N & Mean & Std. Deviation & $\begin{array}{l}\text { Std. } \\
\text { Error } \\
\text { Mean }\end{array}$ \\
\hline Leverage & 1 & 6 & 0.1317 & 0.1733 & 0.0707 \\
& 0 & 72 & 0.9915 & 2.2352 & 0.2634 \\
\hline Roa & 1 & 6 & -1.6717 & 3.4672 & 1.4155 \\
& 0 & 72 & -3.8049 & 28.5075 & 3.3596 \\
\hline
\end{tabular}

Source: Estimation results

The descriptive statistic result shows that age, size, and current ratio have smaller deviation standard than mean (Table 2). This shows that data does not spread. Yet, that does not apply with variables of sales growth, leverage and ROA that have bigger deviation standard than mean. This shows that data relatively spreads.

What is tested next is whether there is influence between variables of age, size, growth and current ratio towards leverage. Table 3 shows the regression result after function complies with the requirements of classic assumption, namely data is normal, free of autocorrelation, free of multicollinearity and free of heteroscedacity. For small and medium-sized businesses in Indonesia, capital structure is affected significantly by variables of the age of company, company size, and company liquidity. On the other hand, growth variable measured by sales growth does not have an effect on the capital structure of the company.

The age of company has significant influence towards capital structure. The older the age of the company, the greater the leverage of the company is. The average age of small and mediumsized businesses listed in Indonesia Stock Exchange is 5.42. The older the age of the company means the more experienced the company so it allows the company to seek external funds so that the capital structure of the company is very high and the capital structure is not conservative. The leverage average of small and medium-sized businesses listed in Indonesia Stock Exchange is 0.9254 .

Table 3. Statistical Results

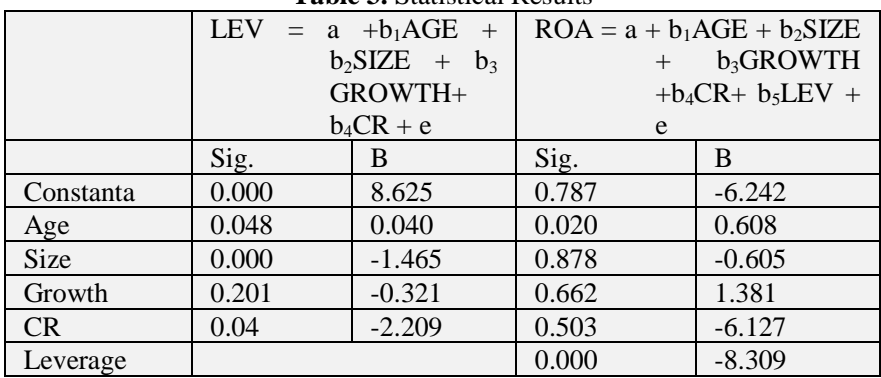

Source: Estimation results

The greater size of the company, the smaller the leverage is. The average size of small and medium-sized businesses listed in Indo- nesia Stock Exchange is 5.42. Maximum value of 7.01 and minimum value of 3.7 show that most companies are relatively medium in size. The sales growth of companies does not affect significantly towards the capital structure of small and medium-sized businesses listed in Indonesia Stock Exchange. On average, the growth rate of companies is $20 \%$. However, most companies have lower growth rate. The greater liquidity of the companies the smaller capital structure of the companies. Liquidity shows the ability of companies to pay the current liability. The average liquidity of small and medium-sized businesses listed in Indonesia Stock Exchange is $34.38 \%$. The lower the liquidity, the higher the capital structure is, which is proven with the high leverage average of the companies. This study is consistent with [1], [[13], [8] that found that financial leverage is positively affected by firm size. This study consistent wiyh [10] that found leverage is negatively effect to ROA but not consitent with that showed that financial accounting performance (ROA) is positively related with company size. Study of [18] in Jordania and [8] also found the same result, but [17] in Malaysia found there is no relation between capital structure and firm performance.

Statistical test result towards dependent variables of company performance in Table 3 shows that it is only the age of the company as a variable that affect significantly. Meanwhile other variables, including company size, company growth and liquidity do not have significant influence. ROA is an indicator of company performance. The older the age of the company, the better performance of the small and medium-sized businesses listed in Indonesia Stock Exchange. The older the age of the company shows that the company has the ability to survive to keep operating by maintaining a good performance. However, this study also indicates that company size does not influence the company performance. The company size does not become a factor that determines the company performance. This is due to the fact that companies that are relatively large or small could be inefficient that it does not affect the performance.This also applies for the sales growth of companies. Since the sales growth of the small and medium-sized businesses listed in Indonesia Stock Exchange is relatively low, its influence of company performance is not strong.

Although liquidity has a significant effect on capital structure of companies, it does not pose a significant effect on company performance. Performance is more influenced by factors directly related to achievement of performance. On the other hand, liquidity shows more about how companies are able to pay the current liability.

Leverage is a capital structure indicator of companies that shows the significant effect towards the performance of the small and medium-sized businesses listed in Indonesia Stock Exchange in negative direction. It means the greater leverage the smaller the performance. This is supported by the data showing the average leverage of companies that is relatively high (0.9254), while the average of ROA is -3.6408 that means most companies suffered losses during the research period.

This study indicates that women who have the tendency to avoid risk will be careful in making financial decisions so even though not significant, the performance of women-owned firms is better than those owned by men. It is also known that the small and medium-sized businesses listed in Indonesia Stock Exchange do not apply a conservative capital structure; on average these companies have relatively large proportion of debt. They also have relatively poor performance indicated by the average value of negative ROA The implication is that if companies want to have good performance, they should maintain their capital structure in a relatively low rate, and it means companies must be able to maintain that the company size is not too big and strengthen liquidity. Because the age of companies is proven well to companies' leverage and performance, then becoming companies that survive in the future is a necessity.

On average, small and medium-sized businesses led by women have better performance than those led by men. This indicates that women who tend to avoid risk will be more careful in making 
decision so they have better performance. There is no difference in capital structure and performance between small and mediumsized businesses owned by men and women. The same applies with ROA, there is no difference between small and medium-sized businesses owned by men and women. There is no leverage difference between small and medium-sized businesses owned by men and women. For small and medium-sized businesses in Indonesia, the capital structure is influenced significantly by age of company, company size and company liquidity variables. On the other hand, growth variable measured by sales growth does not affect the capital structure of companies. Based on statistical test result towards dependent variables of company performance, it is only the age of company as a variable that has significant effect. As for other variables, including company size, company growth and liquidity, do not have a significant effect.

Therefore, if a company wants to have good performance, it is encouraged that the company should maintain its capital structure in a relatively low rate, and it means that the company should maintain its size not to be too large and strengthen its liquidity. Because the age of company significantly affects leverage and performance of the company, then becoming a company that keeps surviving in the future becomes a necessity.

\section{Conclusions}

On average, small and medium-sized businesses led by women have better performance than those led by men. This indicates that women who tend to avoid risk will be more careful in making decision so they have better performance. There is no difference in capital structure and performance between small and mediumsized businesses owned by men and women. The same applies with ROA, there is no difference between small and medium-sized businesses owned by men and women. There is no leverage difference between small and medium-sized businesses owned by men and women. For small and medium-sized businesses in Indonesia, the capital structure is influenced significantly by age of company, company size and company liquidity variables. On the other hand, growth variable measured by sales growth does not affect the capital structure of companies. Based on statistical test result towards dependent variables of company performance, it is only the age of company as a variable that has significant effect. As for other variables, including company size, company growth and liquidity, do not have a significant effect.

Therefore, if a company wants to have good performance, it is encouraged that the company should maintain its capital structure in a relatively low rate, and it means that the company should maintain its size not to be too large and strengthen its liquidity. Because the age of company significantly affects leverage and performance of the company, then becoming a company that keeps surviving in the future becomes a necessity.

\section{References}

[1] A. Gill \& N. Mathur, "Factors that influence financial leverage of Canadian firms. Journal of Applied Finance and Banking, 1(2), 2001. pp. 9-37.

[2] A. Gill, N. Biger. C. Pai. \& S. Bhutani, "The determinants of capital structure in the service industry: evidence from United States," The Open Business journal, 2, 2009. Pp. 48-53.

[3] Alicia M. Robb \& Susan Coleman, "The Impact of Financial Capital on Business Performance: A Comparison of Women- and MenOwned Firms," SSRN Electronic Journal (Mei). 2009.

[4] Barbara J. Orser Allan, L. Riding \& Kathryn Manley. (2006). Women Entrepreneurs and Financial Capital. Entrepreneurship Theory \& Practice, 643-665.

[5] Candida Brush, Nancy Carter, Elizabeth Gatewood, Patricia Greene \& Myra Hart. (2001). The Diana Project: Women Business Owners and Equity Capital: The Myths Dispelled. Kansas City, Mo.: Kauffman Center for Entrepreneurial Leadership.
[6] Du Rietz, Anita \& Magnus Henrekson, "Testing the Female Underperformance Hypothesis," Small business Economics. 14, 2000. Pp.1-10.

[7] Franco Modigliani \& Merton H. Miller, "The Cost of Capital, Corporation Finance and the Theory of Investment," The American Economic Review, 48 (3),2. 1958.

[8] G. Huang \& F.M. Song, "The determinants of capital structure: Evidence from China. China Econ. Rev. 17, 2006. Pp. 14-36.

[9] G.C. Ross, "The determinant of Financial Structure: The incentive signalling approach," Bell Journal of Economics \& Management Science (Spring). 1977, pp. 23-40.

[10] Georgeta Vintilă \& Elena Alexandra Nenu, "An Analysis of Determinants of Corporate Financial Performance: Evidence from the Bucharest Stock Exchange Listed Companies," International Journal of Economics and Financial Issues. 5(3), 2015. Pp.732-739.

[11] Gry Agnete Alsos, Espen John Isaksen \& Elisabet Ljunggren, "New Venture Financing and Subsequent Business Growth in Menand Women-Led Businesses," Entrepreneurship Theory \& Practice, 667-686. 2006

[12] H. DeAngelo and R. Masulis. (1980). Optimal capital structure under corporate and personal taxation. Journal of Financial Economics. 8, 3-29.

[13] J.P. Esperanca, A.P. Gama \& M.A. Gulamhussen, "Corporate debt policy of small firms: an empirical (re)examination", Journal of Small Business and Enterprise Development, 10(1), 2003. Pp.6280.

[14] John A. Weinberg, "Firm Size, Finance, and Investment. Federal Reserve Bank of Richmond Economic,” Quarterly (Winter), 1994. Pp.19-40.

[15] Lisa K. Gundry, Rebel A. Cole \& John D. Wolken, "Financial Services Used by Small Businesses:Evidence from the 1993 National Survey of Small Business Finances," Federal Reserve Bulletin. (July), 1995. Pp. 629-667.

[16] M Jensen \& W. Meckling, "Theory of the firm: Managerial behavior, Agency cost and Ownership structure," Journal of Financial Economic. 3, 1976. Pp. 305-360.

[17] O.T. San \& T.B. Heng, "Capital structure and corporate performance of Malaysian construction sector," Int. J. Humanities Soc. Sci. 1, 2011, pp. 28-36.

[18] R. Zeitun \& G.G. Tian, "Capital structure and corporate performance: Evidence from Jordan,” Aust. Account. Bus. Finance J. 1: 2007. Pp.40-53.

[19] Robert W. Fairlie \& Alicia M. Robb, " Gender Differences in Business Performance: Evidence from the Characteristics of Business Owners Survey," Working paper. 2008.

[20] Sheridan Titman \& Roberto Wessels, "The Determinants of Capital Structure Choice," Journal of Finance, 43; 1988. Pp.1-19.

[21] Stewart C. Myers, "The Capital Structure Puzzle," The Journal of Finance. 39 (3), 1984, pp. 575-592.

[22] Susan Coleman (2011). Small Firm Use of Leverage: A Comparison Men and Women- Owned Firms. www.researchgate.net/publication/242084649.

[23] T.I. Eldomiaty,"Determinants of corporate capital structure: evidence from an emerging economy. International Journal of Commerce \& Management, 17(1/2), 2007. Pp. 25-43.

[24] Timothy Bates \& Alfred Nucci (1989). An Analysis of Small Business Size and Rate of Discontinuance. Journal of Small Business Management. 68-74. Penyakit Kelamin dengan Metode Decision Tree dan Certainty Factor". Seminar Nasional Informatika Medis (SNIMED) VIII.

[5] Kusumadewi, Sri. 2003. Artificial Intelligence (Teknik dan Aplikasinya). Yogyakarta: Graha Ilmu.

[6] Kusnawi, 2007. Pengantar Solusi Data Mining. Seminar Nasional Teknologi (SNT). STMIK Amikom Yogyakarta, D-1 - D-9.

[7] Yusuf, Y.W. 2007. Perbandingan Performansi Algoritma Decision Tree C5.0, CART, dan CHAID: Kasus Prediksi Status Resiko Kredit di Bank X. Seminar Nasional Aplikasi Teknologi Informasi (SNATi). B59 - B62.

[8] Turban, E. 2005. Decision Support System and Intelligent Systems. Yogyakarta: Penerbit Andi.

[9] Kusumadewi, Sri. 2003. Artificial Intelligence (teknik dan aplikasinya). Yogyakarta : Penerbit Graha Ilmu.

[10] Nazir, M., 2005. Metode Penelitian. Bogor: Ghalia Indonesia 